\title{
The Factor Determinants of Regional Origional Revenue in West Sumatra Province
}

\author{
Syofria Meidona ${ }^{1}$, Yolanda $^{2}$, Sumarni $^{2}$, Elsya Meida Arif $^{2}$, Della Maretha $^{2} \&$ Heru Subiyantoro $^{2}$ \\ ${ }^{1}$ Student University of Borobudur Jakarta, Indonesia \\ ${ }^{2}$ University of Borobudur Jakarta, Indonesia \\ Correspondence: Yolanda, University of Borobudur Jakarta, Indonesia. E-mail: yolanda@borobudur.ac.id
}

Received: November 3, 2021; Accepted: November 20, 2021; Published: November 22, 2021

\begin{abstract}
This study aims to determine the effect of Labor Force Participation Rate, Number of Motorized Vehicles, Number of Small and Medium Enterprises, number of tourist Visits, average per capita expenditure, Room Occupancy Rate, and Regional Original Revenue in 19 Cities and Regencies in West Sumatra in 2005-2018. The model used is the OLS method using panel data and using the statistical program e-views 10 for Windows. The results of the study showed either partially or simultaneously that: Labor Force Participation Rate, Number of Motorized Vehicles, Number of Small and Medium Enterprises, Number of Tourist Visits, Average per capita expenditure and Room Occupancy Rate to Regional Original Income are positive and significant. The largest contribution to Regional Original Revenue is Motorized Vehicles, while the lowest is the Hotel Room Occupancy Rate. The coefficient of determination or goodness of fit is 0.742869 . The contribution of all independent variables in explaining the dependent variable is 74.29 percent. Other variables outside the research model explain the remaining 25.71 percent.
\end{abstract}

Keyword: Labor Force Participation Rate, Number of Motorized Vehicles, Number of Small and Medium Enterprises, Number of Tourist Visits, Average per capita expenditure, Room Occupancy Rate and Regional Original Revenue

\section{Introduction}

In Indonesia, each region is given the right to carry out autonomy by providing broad, real and responsible authority that can guarantee regional development and development. Regional autonomy is the right, authority, and obligation of autonomous regions to regulate and manage their government affairs and the local community's interests following applicable laws and regulations.

Law Number 23 of 2020 concerning Financial Balance between the Central Government and Regional Governments states that the sources of regional income consist of: (1) Regional Original Revenue; (2) Balancing funds include profit-sharing funds, general allocation funds, and special allocation funds; (3) Regional loans, (4) Other legitimate regional income.

Indonesia consists of 34 provinces or local governments, and each has a different income and is highly dependent on the three things mentioned above. Specifically, for Regional Original Revenue consists of the results of regional taxes, regional levies, the results of separated regional wealth management, and other legitimate Regional Original Revenue. Regional Original Revenue is obtained from sources within its territory which are collected based on regional regulations following applicable laws and regulations. The amount of Regional Original Revenue can facilitate the implementation of regional development.

Regional Original Revenue is one of the regional revenues and reflects the level of regional independence. The greater the Regional Original Revenue indicates that the region can implement fiscal decentralization, and the dependence on the central government is reduced. The region that has the largest Regional Original Revenue in 2018 is DKI Jakarta at 43.3 trillion, and this value is far above other regions. Moreover, the lowest local revenue is North Maluku 190.9 billion. Regional Original Revenue in each region has not reduced dependence on the central government because its revenue is still far below the regional budget.

West Sumatra Province consists of 19 regencies/cities (12 regencies and seven cities) with the northern boundaries with North Sumatra Province, in the east with Riau and Jambi provinces, in the south with Bengkulu Province, and in the west bordering the Indian Ocean with an area of 40,013 $\mathrm{Km}^{2}$ and a population of 5,441,197 people. 


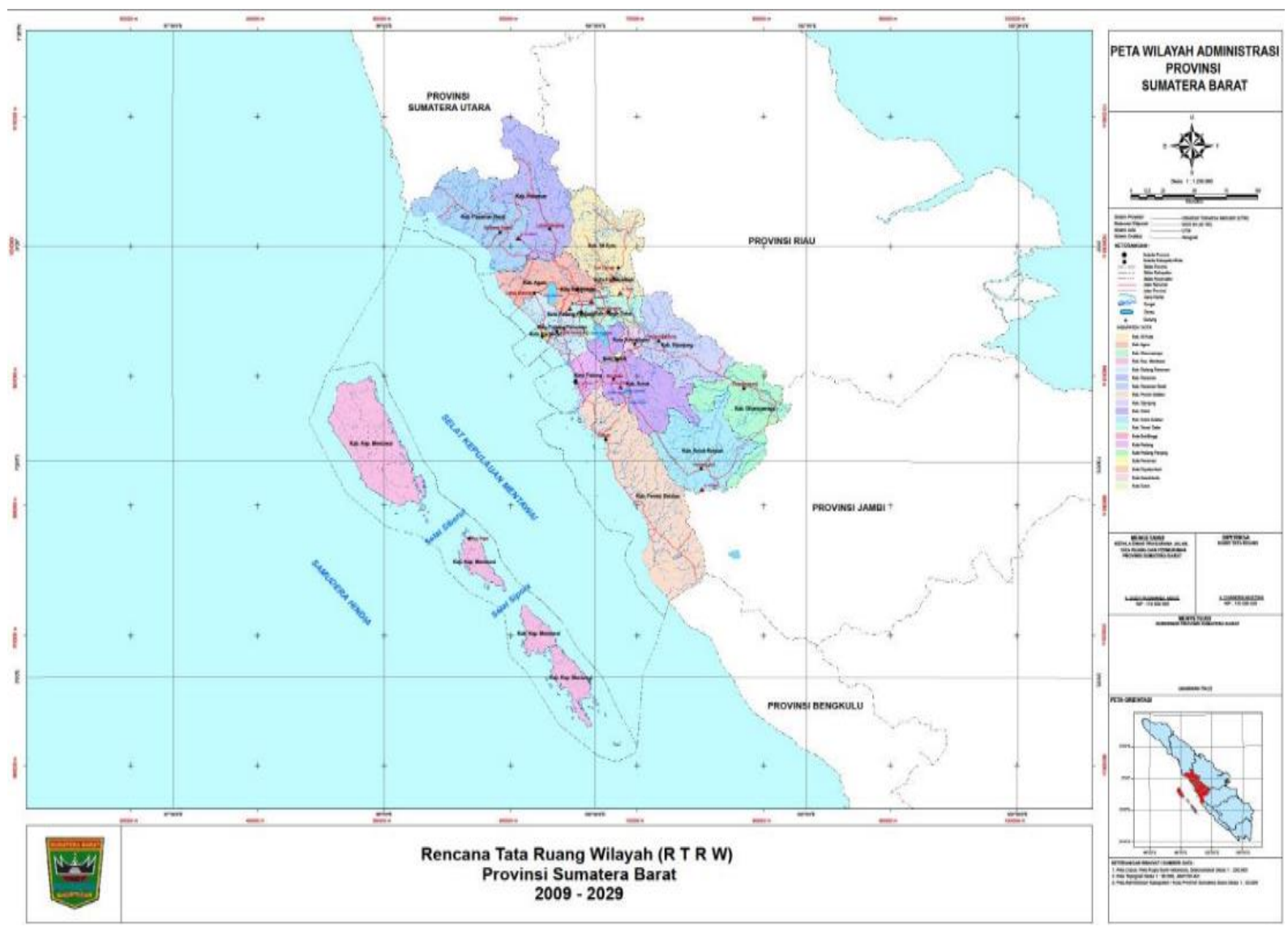

Figure 1. West Sumatra Province Administration Map

The source of income from the province of West Sumatra to finance regional development is the Regional Original Revenue. Revenue obtained by the region from sources within its territory collected under the law, Transfer Revenue which is income from other reporting entities, such as the central government or other autonomous regions in the context of financial balance and other legitimate income. Regional Original Revenue consists of local tax revenue, regional levy revenue, general service levy, business service levy, certain licensing fees, other legal fees, current account service receipts and income from returns.

The comparison of the growth of the average revenue of Indonesia's regional revenue with the original regional income for the province of West Sumatra can be seen in the following table.

Table 1. Growth of Average Regional Original Revenue in Indonesia and Average Regional Original Revenue in West Sumatra Province Year 2010 - 2018

\begin{tabular}{lllll}
\hline No & Year & $\begin{array}{l}\text { Regional Original Revenue Growth } \\
\text { West Sumatra }\end{array}$ & $\begin{array}{l}\text { Average Growth Regional Original Revenue of } \\
\text { Provinces in Indonesia }\end{array}$ \\
\hline 1 & 2014 & 32,65 & 19,54 \\
2 & 2015 & 8,53 & 4,98 \\
3 & 2016 & 4,66 & 4,46 \\
4 & 2017 & 8,65 & 12,11 \\
5 & 2018 & 194,86 & 6,30 \\
& Average & 49,87 & 9,48 \\
\hline
\end{tabular}

Source: BPS Indonesia 2019

Based on the table above, it can be seen that the average growth/year of Regional Original Revenue for the province of West Sumatra is $49.87 \%$ (2014-2018), this shows that the Regional Original Revenue of West Sumatra is above the average Indonesian Regional Original Revenue of 9, 48\%. This condition is because, in 2018, there was a very 
significant increase, namely $194,86 \%$ in West Sumatra Province. Seeing the potential for a significant increase in Regional Original Revenue in 2018 , it is necessary to conduct research. The research conducted is what drives the increase in Regional Original Revenue.

Several studies on Regional Original Revenue growth can be driven by: Labor Force Participation Rate, Number of Motorized Vehicles, Small and Medium Enterprises, Number of Tourist Visits, Per capita Expenditure and Room Occupancy Rate. Research on this was carried out by, among others, (1) Ghani Satria Hartanto and Dewi Kurnia Sugiharti(2019) and Nurfitriana and Andhy Saputra (2020) regarding Motorized Vehicle Taxes on Regional Original Income. (2) Gde Bhaskara Perwira Jaya and A.A Bagus Putu Widanta (2014), Febri Umar Doni (2018), Suprihati, LMS1 et al (2018) and Rahmad et al (2019); about the factors that affect Regional Original Revenue. (3) Yustisia Kristiana et al. (2020); on tourism and Regional Original Revenue.

Under the description above, the main objective to be achieved in this study is to see the factors that influence the growth of Regional Original Revenue in 19 Cities and Regencies in West Sumatra. The factors that influence this growth that wants to be examined are the Labor Force Participation Rate, the number of motorized vehicles, the growth of small and medium enterprises, the number of tourist visits, per capita expenditure, the room occupancy rate on local revenue.

An illustration of the factors that influence the development of this original regional income is the Labor Force Participation Rate in West Sumatra in the last five years which tends to increase with 67.69. This Regional Original Revenue is still below the average for Indonesia (67.77). The number of motorized vehicles tends to increase (2016-2019) and in 2020 to decrease (covid-19 pandemic conditions). The number of motorized vehicles in West Sumatra is still below $1 \%$ of the number of vehicles in Indonesia. The number of Small and Medium Enterprises in West Sumatra has increased over the last five years, but the number is still below $1 \%$ of Indonesia's total. Based on the results of the March 2020 National Socio-Economic Survey, the average monthly expenditure per capita of the population of West Sumatra was 6.02 percent higher than in 2019. This increase in average expenditure occurred in spending on food, which was around 50 percent. The room occupancy rate for five-star hotels in West Sumatra in 2020 was recorded at 35.34 percent, and this value is far below the room occupancy rate in 2019 $(56.00 \%)$. It is due to the 2020 government policies limiting people's mobility.

Referring to the background described above, the purpose of this study is to find out how the influence of Labor Force Participation Rate, Number of Motorized Vehicles, Number of Small and Medium Enterprises, average expenditure per capita, and Room Occupancy Rate on the growth of regional original income either simultaneously or partial.

\section{Literature Review}

\subsection{Regional Original Revenue}

Based on Law no. 33 of 2004: "Regional Original Revenue is the income obtained by the region which is collected based on Regional Regulations in accordance with statutory regulations. Meanwhile, Djaenuri (2012) stated that Regional Original Revenue is income for the region that comes from the region itself based on the applicable regional regulations. While Budi S. Purnomo (2009), regional original income is regional income sourced from regional taxes, regional retribution proceeds, separated regional wealth management results and other legitimate regional original income, which aims to give authority to local governments. to fund the implementation of regional autonomy in accordance with regional potential as a manifestation of decentralization".

According to Rahmad et al. (2019); Regional Original Revenue is divided into several types of revenue, including regional taxes, regional levies, regional company proceeds, and distributed regional wealth management results, and other legitimate Regional Original Revenue s and Erlina (2015) states that Regional Original Revenue can be grouped into three categories, namely Regional Original Revenue through stipulation, Regional Original Revenue without stipulation from Guarantee Execution Results.

According to Noor Farieda Awwaliyah et al. (2019), the ability of a region to explore Regional Original Revenue will affect the development of the region, and the greater the contribution of original regional revenue to the total regional budget, the better the government's performance. The regional government can increase Regional Original Revenue through Regional Taxes, Regional Levies, Separate Regional Assets Management Results, and Other Legitimate Regional Original Revenues to the maximum or by expanding other regional tax objects.

\subsection{Labor Force Participation Rate}

The labor force participation rate refers to the percentage of the population over 15 who are considered active workers. While in the United States, the Labor Force Participation Rate is defined as the number of people in the 
labor force as a percentage of the non-institutional civilian population 16 years and over (Patrick J. Litzinger et al., 2015).

According to Simanjuntak (2005), in general, Labor Force Participation Rate (LFPR) can be formulated:

$$
\begin{gathered}
\text { Number of labor force } \\
\text { Number of working age population (labor) }
\end{gathered}
$$

According to the Indonesian Central Statistics Agency (2005), the high Labor Force Participation Rate indicates the increasing trend of the productive age population (15-64 years) in seeking and carrying out economic activities. Meanwhile, Simanjuntak, 2001 in Sukidin, 2015 stated that the level of labor force participation describes the effect of population participation in productive economic activities. The higher the non-labor force, the smaller the number of the labor force and the smaller the labor force participation rate.

\subsection{Motor Vehicle}

A motorized vehicle is any vehicle driven by mechanical equipment in the form of machines other than vehicles that run on rails, consisting of individual motorized vehicles and general motorized vehicles. Non-motorized vehicles are vehicles driven by human or animal power (UU RI No. 22 of 2009). Types of motorized vehicles (RI Law No. 22 of 2009) are bicycles, passenger cars, buses, goods cars, and special vehicles. The ownership and use of this motorized vehicle will be taxed.

Motor vehicle tax is one of the levels I regional taxes, which is levied on ownership of a motorized vehicle, imposed for a tax period of 12 consecutive months, starting from the time of registration, and paid at once in advance. This tax will increase along with the increase in the number of motorized vehicle ownership due to the increase in the community's economy. The increase in the number of motorized vehicles is due to the ease of purchasing vehicles on credit. Purchases of vehicles on credit only need to be done by paying a certain down payment and then making the remaining payments gradually over a certain period. Motor vehicle ownership has a close relationship with taxes, which according to Suprihati (2018); tax is a mandatory contribution to the state. The motor vehicle tax is local revenue.

\subsection{Small and Medium Enterprises (SMEs)}

Law number 3 of 2014 concerning industry has put industry as one of the pillars of the economy and gives the government a large enough role to encourage the progress of national industry in a planned manner. According to Narain (2003), contributions from micro, small and medium enterprises (MSMEs) include providing jobs. Furthermore, Tambunan (2009) divides these companies into three categories, namely especially micro-enterprises (MIEs), small enterprises (SMEs), and medium enterprises (MEs), and each has characteristics based on location, market, production, organization, and management, Sources of inputs, external networks.

Meanwhile, according to Kadiri (2012), the Development of Small and Medium Enterprises (SMEs) catalyzes job creation, national growth, poverty reduction, and economic development. Moreover, Ramadhilla Maghfira Utami and Donald Crestofel Lantu (2013) stated that Small and Medium Enterprises (SMEs) are a safety valve in national economic recovery. Their role in economic growth and rapid employment is the starting point for moving the production sector in various business fields. While Chuma-Makandwire (2004) that Small and Medium Enterprises play an important role in poverty alleviation, social growth, and economic development. One indicator of the development of small industries is by looking at business growth.

\subsection{Tourist Visit}

The Indonesian Central Bureau of Statistics defines foreign tourists as any person who visits a country outside their place of residence, driven by one or more needs without the intention of earning income at the place visited and the duration of the visit is not more than 12 (twelve) months, and this definition is under with the recommendation of the United Nations World Tourism Organization (UNWTO). In addition, the World Tourism Organization (WTO) mentions the number of tourists due to the total number of non-indigenous people who come for short trips. Meanwhile, according to Kadek Dewi Udayantini et al. (2015), the number of tourists is the total number of domestic and foreign tourists who visit or come to a place that is not their residence a vacation. This tourist visit consists of visits by domestic tourists and visits by foreign tourists.

The arrival of tourists will bring acceptance for the area visited. The more tourists who visit it will positively impact the Tourist Destination Area (TDA), especially as a source of regional income (Nasrul, 2010). Furthermore, 
according to Windanila Sri Kuswari et al. (2021), the number of foreign tourists and domestic tourists has a positive and significant effect on the growth of Regional Original Revenue in contrast to the research results of Putu Widyaningsih and Made Kembar Sri Budhi (2014) which stated that the research results were not significant.

\subsection{Per capita Expenditure}

The Indonesian Central Bureau of Statistics (ICSA) stated that per capita expenditure is the cost incurred for the consumption of all household members for a month divided by the number of household members adjusted for purchasing power parity. The composition of household expenditure can be used to assess the level of the economic welfare of the population. The forms of Expenditure are Household Consumption Expenditure (HCE), Consumption Expenditure of Non-Profit Institutions serving households (CE-NPISH), Government Consumption (GC), Gross Fixed Capital Formation (GFCF). Alisjahbana, A. S. (2003) states that consumption expenditures are costs incurred due to spending made by individuals, the government, and the private sector. To determine the variable per capita expenditure in this study using the formula used by Sanford et al. (2001) (in Gatot 2010) as follows.

Expenditure per capita $=\underline{\text { Total regional expenditure }}$

Total population

\subsection{Hotel Room Occupancy Rate}

According to Lawson (1976), a hotel is housing for travelers with room service, food and beverage facilities, and accommodation with payment terms. While the AHMA (American Hotel and Motel Associations) hotel is a place where lodging, food, and drinks are provided and other services for rent for guests or people who stay temporarily. Thus, the hotel consists of rooms, and these rooms have facilities for people who occupy them temporarily.

Room occupancy rate is the room occupied or rented out to guests compared to the number of rooms rented, estimated in days, months, or years times 100 percent (According to Damardjati, 2006). Meanwhile, the room occupancy rate is highly dependent on price, competition, and demand (Yoeti (2008). Meanwhile, Suarthana (2006) stated that other factors that affect the room occupancy rate are hotel location, hotel facilities, room service, room rates or room rental rates, and promotion.

\section{Research Methods}

The object of research is something that is the focus and target of a study. In this study, the research object is local revenue and the factors that influence it, namely Labor Force Participation Rate, Number of Motorized Vehicles, Number of Small and Medium Enterprises, number of tourist visits, average expenditure per capita, Hotel Room Occupancy Rate.

The type of data used in this study is secondary data in the form of time-series data (time series) under data availability for each variable studied. This study uses annual time series data from 2005-2018 from 19 cities and regencies in the West Sumatra area. The data was obtained from various sources, namely the Indonesian Central Statistics Agency and the Regional Central Statistics Agency. Besides, this research uses panel data or panel model regression, and the data processing and analysis in this study are carried out with the help of the statistical program Eviews 10 for Windows. Panel data regression provides a choice of models in common effects, fixed effects, and random effects. The common effects and fixed effects models use the Ordinary Least Squared (OLS) approach, while the random effects use Generalized Least Squares (GLS). To determine and choose the right panel data model from the three existing data panels of regression estimation models, Chow test, Hausman test, and Lagrange Multiplier (LM) test are needed.

If the model chosen is the common effect or fixed effect, the classical assumption test that must be carried out includes the heteroscedasticity test and multicollinearity test. Meanwhile, if the selected model is a random effect, there is no need to test the classical assumptions. However, it is better to test the classical assumptions in the form of normality, autocorrelation, heteroscedasticity, and multicollinearity tests to be carried out on any selected model to know whether the model formed meets the BLUE (Best Linear Unbias Estimator) requirements.

Determining and selecting the right panel data model is from the three existing estimation data panel models necessary to test the Chow, Hausman, and Lagrange Multiplier (LM) tests. To determine how far the independent variables partially have an individual influence on the dependent variable using the t-test. Meanwhile, to find out how far the independent variables partially have an individual influence on the dependent variable, the t-test is used.

Linear Multiple Regression Equation (Multiple Linear Regression) is as follows: 


$$
\mathrm{ROR}=a_{0}+\beta_{1} \mathrm{LFPR}_{i t}+\beta_{2} \mathrm{NMV}_{i t}+\beta_{3} \mathrm{SMEs}_{i t}+\beta_{4} \mathrm{NTV}_{i t}+\beta_{5} \mathrm{PE}_{i t}+\beta_{5} \mathrm{HROR}_{i t}+e_{i t}
$$

Note:

$\mathrm{ROR}=$

LFPR $=$ Labor Force Participation Rate

NMV $=$ Number of Motorized Vehicles

SMEs $=$ Small and Medium Enterprises

NTV = Number of Tourist Visits

$\mathrm{PE}=$ Per capita Expenditure.

HROR $=$ Hotel Room Occupancy Rate

$\alpha=$ Constant Number (Intercept)

$\beta_{i}=$ Regression Coefficient

$\mathrm{e}_{1 \mathrm{t}}=$ Error term

To measure how far the model's ability formed to explain the variation of the independent variables, the coefficient of determination $\left(\mathrm{R}^{2}\right)$ is used. Furthermore, a good research model is required to meet the characteristics specified in an econometric model (the goodness of an econometric model), then a theory suitability test is carried out.

\section{Hypothesis}

To answer the above problems by using theories that are related to the research problem and not based on facts and real data support in the field, the form of the research framework is as follows

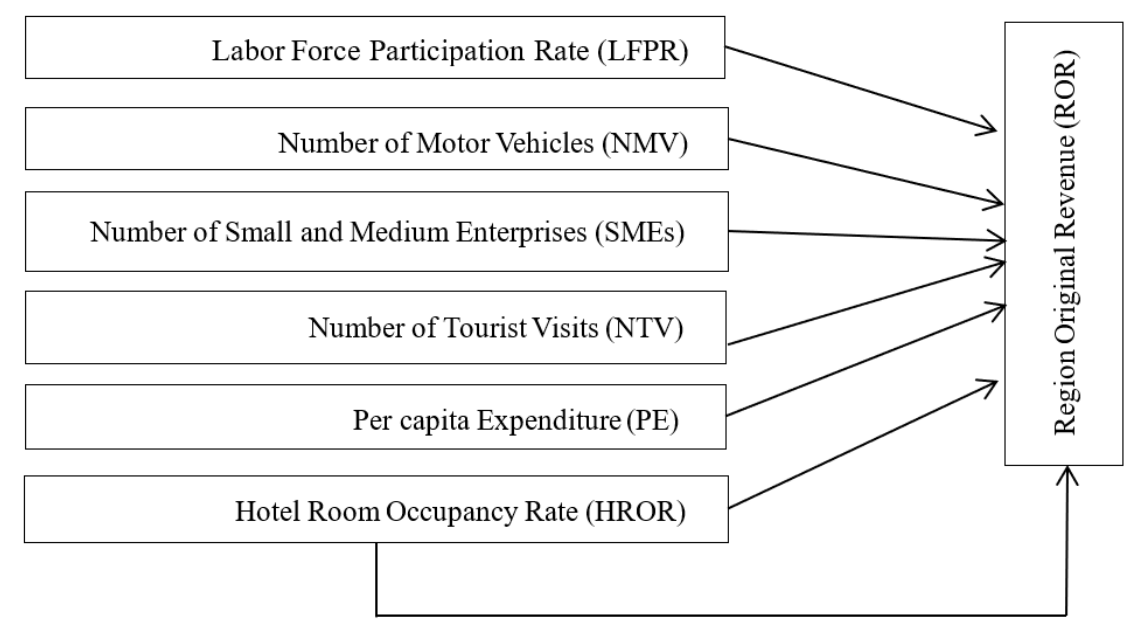

Figure 2. Research Framework

Source: Processed 2021

Based on the above framework, the following hypotheses were obtained:

1. The labor force participation rate, the number of motorized vehicles, the growth of large and medium industries, the number of tourist visits, per capita expenditure and hotel room occupancy rates simultaneously have a positive and significant effect on Regional Original Revenue (ROR).

2. The labor force participation rate (LFPR) has a positive and significant effect on Regional Original Revenue (ROR)

3. The number of motorized vehicles (NMV) has a positive and significant effect on Regional Original Revenue (ROR).

4. The number of Small and Medium Enterprises (SMEs) has a positive and significant effect on Regional Original Revenue (ROR).

5. The number of tourist visits (NTV) has a positive and significant effect on Regional Original Revenue (ROR).

6. Per capita Expenditure (PE) has a positive and significant effect on Regional Original Revenue (ROR). 
7. Hotel Room Occupancy Rate (HROR) has a positive and significant effect on Regional Original Revenue (ROR)

\section{Research Results and Discussion}

Classical assumption tests include Multicollinearity, Heteroscedasticity, and Autocorrelation tests. They aimed to determine whether the estimated regression model is the Best Linear Unbiased Estimator (BLUE), and the results of the Normality, Multicollinearity, Heteroscedasticity and Autocorrelation tests state that the data has no problems.

Panel data regression was carried out with three models, namely pooled, fixed effect, and random effect, and the best result was Common effect after the Chow, Hausman, and Lagrange Multiplier (LM) tests, and the results were as follows:

Table 4.12 Results of Regression Panel Data Equation Model 1

Dependent Variable: Log ROR

Method: Panel Least Squares

Date: 02/14/21 Time: 21:59

Sample: 20052018

Periods included: 14

Cross-sections included: 19

Total panel (unbalanced) observations: 258

\begin{tabular}{|c|c|c|c|c|}
\hline Variable & Coefficient & Std. Error & t-Statistic & Prob. \\
\hline$\overline{\mathrm{C}}$ & 12.09928 & 1.125761 & 10.74764 & 0.0000 \\
\hline Log LFPR & 0.273029 & 0.063854 & 4.275861 & 0.0000 \\
\hline Log NMV & 0.369751 & 0.039667 & 9.321289 & 0.0000 \\
\hline Log SMEs & 0.215828 & 0.021876 & 9.866116 & 0.0000 \\
\hline Log NTV & 0.178401 & 0.015292 & 11.66612 & 0.0000 \\
\hline Log PE & 0.208331 & 0.067026 & 3.108222 & 0.0022 \\
\hline Log HROR & 0.032868 & 0.014299 & 2.298632 & 0.0227 \\
\hline R-squared & 0.751032 & Mean dependent var & & 24.31911 \\
\hline Adjusted R-squared & 0.742869 & S.D. dependent var & & 0.834948 \\
\hline S.E. of regression & 0.423386 & Akaike info criterion & & 1.155082 \\
\hline Sum squared resid & 32.80383 & Schwarz criterion & & 1.274710 \\
\hline Log likelihood & -102.7328 & Hannan-Quinn criter. & & 1.203542 \\
\hline F-statistic & 92.00564 & Durbin-Watson stat & & 1.886776 \\
\hline Prob(F-statistic) & 0.000000 & & & \\
\hline
\end{tabular}

Source: Processed Data, 2020

The calculation results:

a. The effect of the Labor Force Participation Rate (LFPR) on Regional Original Revenue (ROR) shows positive and significant results on the probability that the labor force participation rate (LFPR) is smaller than $(0.0000<0.05$.

b. The effect of the number of motorized vehicles (NMV) on local revenue (LR) shows positive and significant results on the probability that the number of motorized vehicles is less than $(0.0000<0.05)$.

c. The effect of the number of Small and Medium Enterprises (SMEs) on Regional Original Revenue (ROR) shows positive and significant results on the probability that the number of small and medium industries is smaller than $(0.000<0.05)$.

d. The influence of the number of tourist arrivals or visits (NTV) on Regional Original Revenue (ROR) shows positive and significant results on the probability that the number of tourist visits is smaller than $(0.000<0.05$

e. The effect of Per capita Expenditure (PE) on Regional Original Revenue (ROR) shows positive and significant results on the probability of per capita expenditure less than $(0.0022<0.05)$.

f. The effect of Hotel Room Occupancy Rate (HROR) on Regional Original Revenue (ROR) shows positive and significant results on the probability that the hotel room occupancy rate is lower than $(0.0227<0.05)$. 
The $\mathrm{F}$ test obtained is a probability significance value of $0.0000<0.05$, this indicates that the variables of the labor force participation rate, the number of motorized vehicles, the number of small and medium industries, the number of tourist visits, government spending, hotel room occupancy rates simultaneously have an effect which is significant to Regional Original Revenue.

The Adjusted $\mathrm{R}^{2}$ value is 0.742869 . It shows that the labor force participation rate can explain 74.29 percent of the Regional Original Revenue variable, the number of motorized vehicles, small and medium industries, tourist visits, and per capita expenditure, and hotel room occupancy rates. In contrast, the remaining $25,71 \%$, is explained by other variables not examined in this study.

The results of the model suitability test, based on the results of Theoretical Plausibility, were obtained before the estimation and after the estimation was appropriate. The Accuracy of the Estimate of the Parameters is the statistical error of the low model, which is below 0.05. Meanwhile, Forecasting Ability is above 50\%, which is $74.28 \%$.

The panel data regression equation using the Common effect estimation is as follows:

$\log$ ROR $=12.09928+0.273029 \log$ LFPR + 0.369751 log NMV + 0.215828 log SMEs + 0.178401 log NTV + $0.208331 \log$ PE $+0.032868 \log$ HROR

Based on the above equation can be shown:

a. A constant of 12.09928 means 12.09928; this means that if the LFPR, NMV, SMEs, NTV, PE, and HROR do not change, then the ROR is worth 12.09928

b. The regression coefficient for the LFPR variable is 0.273029 , meaning that for every 1 unit increase in LFPR, it will increase ROR by 0.273029 units, assuming the other independent variables have a fixed value.

c. The regression coefficient for the NMV variable is 0.369751 , which means that for every 1 unit increase in NMV, it will increase ROR by 0.369751 units, assuming the other independent variables have a fixed value.

d. The regression coefficient for the SMEs variable is 0.215828 , meaning that for every lunit increase in SMIs, it will increase ROR by 0.215828 units, assuming the other independent variables have a fixed value.

e. The regression coefficient for the NTV variable is 0.178401 , which means that for every 1 unit increase in NTV, it will increase ROR by 0.178401 units, assuming the other independent variables have a fixed value.

f. The regression coefficient for the PE variable is 0.208331 , meaning that every increase in PE by 1 unit will decrease ROR by 0.208331 units, assuming the other independent variables have a fixed value.

g. The regression coefficient for the HROR variable is 0.032868 , meaning that for every 1 unit increase in HROR, it will decrease ROR by 0.032868 units, assuming the other independent variables have a fixed value.

The description above shows that the coefficients of LFPR, NMV, SMEs, NTV, PEP, and HROR are smaller than one. It shows that large changes in the variables in LFPR, NMV, SMEs, NTV, PE, and HROR only have a small impact on ROR, which is below 40\%, and the smallest impact is on the Total Hotel Room Occupancy Rate (HROR) $3.2 \%$, where the change is positive.

\section{Conclusion}

Based on the study results, the Labor Force Participation Rate has a positive and significant effect on region original revenue. Nineteen cities and regencies show it in West Sumatra that has implemented the concept of expanding off-farm, off-service employment opportunities. These efforts are to increase further and encourage an increase in region original revenue in each district and city in West Sumatra Province.

The number of motorized vehicles has a positive and significant effect on local revenue. It shows that the vehicle tax and tax whitening policies and administrative sanctions for transfer of title for motorized vehicles can boost Regional Original Revenue. Meanwhile, Small and Medium Enterprises also have a positive and significant impact on Regional Original Income.

The number of Tourist Visits has a positive and significant effect on Regional Original Income, which is due to the improvement of tourist destinations, community readiness, supporting facilities and infrastructure, and promotions carried out by 19 Cities and Regencies in West Sumatra that encourage/attract tourists come to 19 cities and regencies in West Sumatra. The increase in tourist visits resulted in a high hotel room occupancy rate. 
This hotel room occupancy rate has a positive and significant effect on region original revenue. Besides that, Per capita Expenditure also has a positive and significant effect on regional original Reveneu

The variables studied showed a positive and significant effect on Regional Original Revenue in 19 cities and districts of West Sumatra Province. It shows that the implementation of policies in the field of employment, the number of motorized vehicles, tourism, small and medium industries are empirically considered appropriate to increase original region revenue. For this reason, the City and District governments will further increase/encourage the increase in Regional Original Revenue through more appropriate regional regulations/policies.

The researcher hopes to generate input for the West Sumatra provincial government in terms of exploring the potential of regional original income, which has an impact on increasing Regional Original Revenue. Thus, development can be carried out optimally, which impacts the community, namely increasing the community's economy in 19 cities and regencies of West Sumatra Province.

\section{Reference}

Alisjahbana, A. S. (2003). Analisis Ekonomi Jawa Barat. Bandung: Unpad Press.

Chuma-Mkandawire, S. (2004), National Economic Consultative Forum. Report on the Policy Implementation Workshop For SMEs, p. 25-27.

Damardjati, R. S. (2006). Istilah-istilah dunia pariwisata. Jakarta: Pradnya Paramita.

Djaenuri, A. (2012). Hubungan Keuangan Pusat - Daerah. Jakarta: Ghalia Indonesia

Ismaila, B. K. (2012). Small and Medium Scale Enterprises and Employment Generation in Nigeria: The Role of Finance, Kuwait Chapter of Arabian Journal of Business and Management Review Vol. 1, No.9, p. 79-93.

Erlina, D. (2015). Akuntansi Keuangan Daerah Berbasis Akrual Berdasarkan PP No. 71 Tahun 2010 dan Permendagri No. 64 tahun 2013. Jakarta Selatan: Salemba Empat.

Febri, U. D. (2018). Analysis of Influencing Factors Regional Original Revenue (PAD) in The Provincial Government of DKI Jakarta, Indonesian Journal of Business, Accounting and Management Vol. 01 No. 01.

Ghani, S. H., \& dan Dewi, K. S. (2019). The Impact Of The Motor Vechicle Tax Award On The Increase of The West Java Province's Locally Generate Revenue. Padjadjaran Journal of Law, 6(1), 168-189. https://doi.org/10.22304/pjih.v6n1.a9

Jaya, G. B. P., \& Widanta, A. B. P. (2014). Analisis faktorfaktor yang berpengaruh terhadap Pendapatan Asli Daerah (PAD) Kota Denpasar. E-Jurnal Ekonomi Pembangunan, 3(5), 201-208Budi, Purnomo S (2009). Obligasi Daerah. Bandung: Alfabeta.

Kadek, D. U., I Wayan Bagia , I Wayan Suwendra (2015). Pengaruh Jumlah Wisatawan Dan Tingkat Hunian Hotel Terhadap Pendapatan Sektor Pariwisata Di Kabupaten Buleleng Periode 2010-2013, e-Journal Bisma Universitas Pendidikan Ganesha Jurusan Manajemen, Volume 3.

Lawson, F. (1976). Hotels, motels, and condominiums: design, planning, and maintenance. London: Architectural Press.

Patrick J. L., \& John, H. D. (2015). The Labor Force Participation Rate: A Rexamination Of The Determinants Of Its Decline. The Journal of Applied Business Research, 31(6), 2283-2296. https://doi.org/10.19030/jabr.v31i6.9484

Putu Widyaningsih dan Made Kembar Sri Budhi (2014), Pengaruh Jumlah Kunjungan Wisatawan Terhadap Penerimaan Pajak Hotel, Pajak Restoran Dan Pendapatan Asli Daerah. E-Jurnal EP Unud, 3(4), 155-163.

Narain, S. (2003). Institutional capacity-building for small and medium-sized enterprise promotion and development. In UN-ESCAP, Investment Promotion and Enterprise Development Bulletin for Asia and the Pacific 2. New York: United Nations

Noor, F. A., Ratno, A., \& Dessy, N. F. (2019). The effect of regional original income and balance funding on regional government financial performance. Journal of Islamic Accounting and Finance Research, 1(1), 2546. https://doi.org/10.21580/jiafr.2019.1.1.3745

Nurfitriana, \& Andhy, S. (2020). Realization Analysis of Received Motor Vehicle Tax And Behavior Of Motor Vehicle Name In The Regional Income Agency of Central Sulawesi Province. Economy Deposit Journal, 2(1), 1-10. https://doi.org/10.36090/e-dj.v2i1.729

Ramadhilla, M. U., \& Donald, C. L. (2013). Development of Competitivenes Model For Small-Medium Enterprises Among The Creative Industry In Bandung. The Indonesian Journal of Business Administration, 
2(11), 1309-1318.

Rahmad, T. Z., \& Chenny, S. (2019). The Analysis Of Local Revenues And The Affecting Factors In The Implementation Of Regional Autonomy In Aceh Province. Journal Ekonomi Dan Kebijakan Publik Indonesia, 6(1), 86-103. https://doi.org/10.24815/ekapi.v6i1.14260

Simanjuntak, P. J. (2005). Ekonomi Sumber Daya Manusia., Jakarta: Fakultas Ekonomi Universitas Indonesia.

Sukidin, M. T. F. (2015). Tingkat Partisipasi Angkatan Kerja Masyarakat Miskin Di Rt.01 Rw.06 Desa Tegal Gede Kecamatan Sumbersari Kabupaten Jember.Jurnal Pendidikan Ekonomi, Edisi IX(2), Mei 2015, Hal 15-25.

Suprihati, L. M. S., Kristiyanti, \& Hajir (2018). Improving Regional Original Income With Tax Receipt, Regional Retribution And Regional Wealth Management Results In Solo Raya. International Journal of Economics, Business and Accounting Research (IJEBAR), 2(3), 11-26. https://doi.org/10.29040/ijebar.v2i3.337

Suarthana. (2006). Manajemen perhotelan edisi kamar depan. Kuta Utara: Mapindo.

Tambunan, T. T. H. 2009a. SME in Asian Developing Countries. London: Palgrave Macmillan Publisher. https://doi.org/10.1057/9780230250949

Windanila, S. K., Abdul, A. A., \& Diah, S. G. ( 2021). The Effect of Tourism Sector on Locally-Generated Revenue Income in Banyumas District. Journal Manajemen dan Sains, 6(1), 164-167. https://doi.org/10.33087/jmas.v6i1.220

Yustisia, K., Rudy, P., Theodosia, C. N., \& Vasco, A. H. G. (2020). Tourism and Original Local Government Revenue in Indonesia Tourism Provinces: The Java Island Experience, a multifaceted review Journal in the field of pharmacy. Sys Rev Pharm, 11(9), 745-750.

Yoeti, O. (2008). Ekonomi pariwisata: introduksi, informasi, dan implementasi. Jakarta: Kompas.

\section{Copyrights}

Copyright for this article is retained by the author(s), with first publication rights granted to the journal.

This is an open-access article distributed under the terms and conditions of the Creative Commons Attribution license (http://creativecommons.org/licenses/by/4.0/). 